\title{
Cyst with a mural nodule: unusual imaging characteristics of a cystic meningioma
}

Chong K Yi, Ricardo M Burgos, Timothy J Biega

Department of Radiology, Tripler Army Medical Center, Honolulu, Hawaii, USA

\section{Correspondence to} Dr Chong K Yi,

chong.k.yi1.mil@mail.mil
CrossMark

To cite: Yi CK, Burgos RM, Biega TJ. BMJ Case Rep Published online: [please include Day Month Year] doi:10.1136/bcr-2013202851

\section{DESCRIPTION}

A 38-year-old man presented with 2 to 3 months of intermittent headaches. Aside from hypertension, the patient was in good health. Physical able. Routine unenhanced head CT (figure 1A,B) and gadolinium enhanced brain MRI (figure 2A-D) revealed a right frontoparietal cystic mass

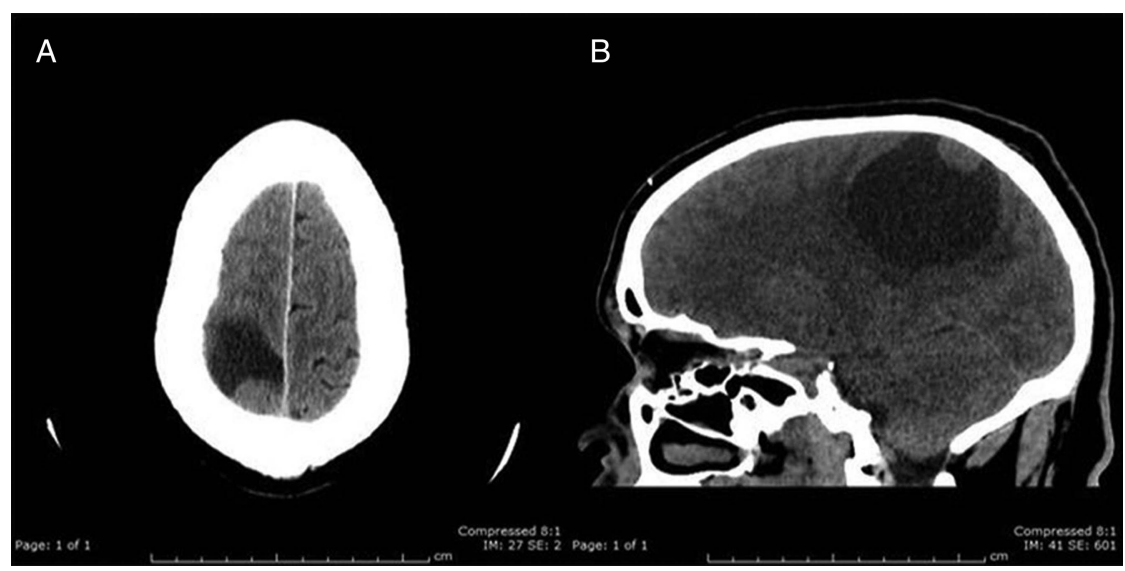

Figure 1 Axial (A) and sagittal (B) head CT revealing a cyst with a mural nodule with minimal peritumoral oedema.

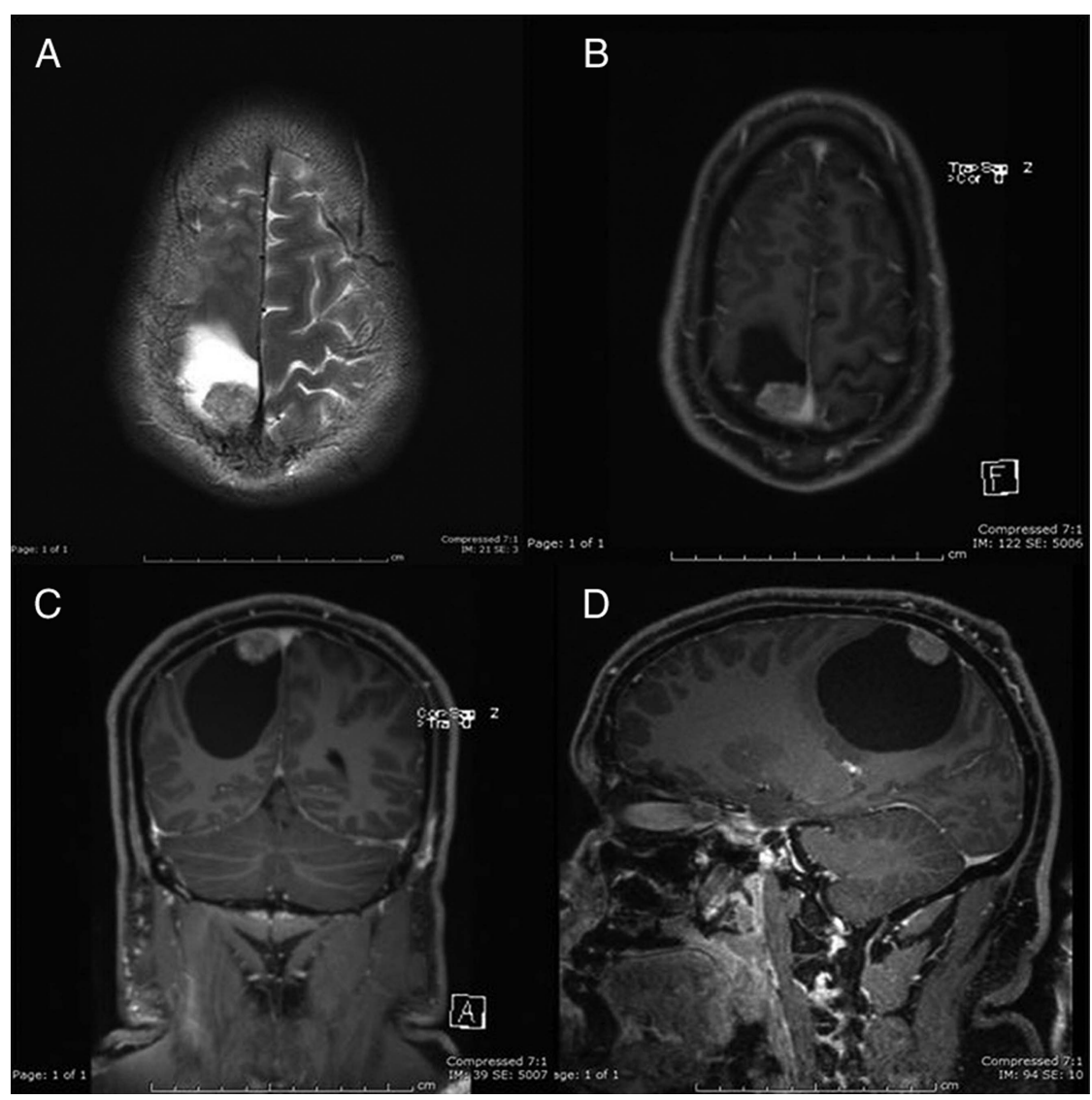

Figure 2 Axial T2 (A), postcontrast axial T1 (B), coronal T1 (C), and sagittal T1 (D) sequences demonstrating a cyst with an enhancing mural nodule. No cerebrospinal fluid cleft, cortical buckling, or a definitive dural tail is evident to suggest an extra-axial neoplasm. 
measuring $6.0 \times 3.9 \times 5.0 \mathrm{~cm}$ with an enhancing mural nodule and minimal peritumoral oedema. Imaging findings were suggestive of a primary glial tumour. The patient underwent surgery and the mass was completely resected. Histopathology revealed meningothelial meningioma with focal microcystic changes, WHO grade 1.

Meningioma is a predominantly benign neoplasm that arises from arachnoid cap cells. It is the most common primary extraaxial neoplasm with associated cysts found in $4-7 \%$ of cases. ${ }^{1}$ Nauta et al classified cystic meningiomas into four categories. Type I: intratumoral cyst is centrally located within the tumour. Type II: intratumoral cyst is peripherally located within the

\section{Learning points}

- Meningioma is the most common extra-axial neoplasm and the most frequently diagnosed primary brain tumour.

- Cystic meningioma with an intraparenchymal cyst can mimic a cyst with a mural nodule found in primary glial neoplasms.

- The aetiology of intraparenchymal cyst is uncertain, but is thought to be secondary to degeneration or an adjacent arachnoid cyst. tumour. Type III: peritumoral cyst is located in the adjacent brain. Type IV: peritumoral cyst is located between the tumour and the brain. ${ }^{2}$ As illustrated in our case (type III), an intraparenchymal cyst can obscure the cerebrospinal fluid trapped between the tumour and parenchyma and mimic an intra-axial neoplasm. The aetiology of intraparenchymal cyst formation is uncertain, but is thought to be due to degeneration or an adjacent arachnoid cyst. $^{3}$ Owing to parenchymal involvement, classic imaging features may be absent and diagnosis may be challenging, radiologically and surgically. The typical differential diagnosis of a cyst with a peripheral nodule includes pleomorphic xanthoastrocytoma, pilocytic astrocytoma, ganglioblastoma and haemangioblastoma. As demonstrated by this case, cystic meningioma should also be considered in this differential.

Competing interests None.

Patient consent Obtained.

Provenance and peer review Not commissioned; externally peer reviewed.

\section{REFERENCES}

1 Osborn AG. Osborn's brain: imaging, pathology, and anatomy. 1st edn. Amirsys, 2012.

2 Nauta HJ, Tucker WS, Horsey WJ, et al. Xanthochromic cysts associated with meningioma. J Neurol Neurosurg Psychiatry 1979;42:529-35.

3 Buetow MP, Buetow PC, Smirniotopoulos JG. From the archives of the AFIP: typical, atypical and misleading features in meningioma. Radiographics 1991;11:1087-106.

Copyright 2014 BMJ Publishing Group. All rights reserved. For permission to reuse any of this content visit http://group.bmi.com/group/rights-licensing/permissions.

BMJ Case Report Fellows may re-use this article for personal use and teaching without any further permission.

Become a Fellow of BMJ Case Reports today and you can:

- Submit as many cases as you like

- Enjoy fast sympathetic peer review and rapid publication of accepted articles

- Access all the published articles

- Re-use any of the published material for personal use and teaching without further permission

For information on Institutional Fellowships contact consortiasales@bmjgroup.com

Visit casereports.bmj.com for more articles like this and to become a Fellow 